\title{
Predominance of precore mutations and clinical significance of basal core promoter mutations in chronic hepatitis B virus infection in Indonesia
}

\author{
JUNIASTUTI $^{1,2}$, TAKAKO UTSUMI ${ }^{2,4}$, EDUARDUS BIMO AKSONO ${ }^{3}$, YOSHIHIKO YANO ${ }^{4}$, \\ SOETJIPTO $^{2,5}$, YOSHITAKE HAYASHI ${ }^{4}$, HAK HOTTA ${ }^{4}$, FEDIK ABDUL RANTAM ${ }^{3}$, \\ HERNOMO ONTOSENO KUSUMOBROTO ${ }^{6}$ and MARIA INGE LUSIDA ${ }^{1,2}$
}

\footnotetext{
${ }^{1}$ Department of Microbiology, School of Medicine, Airlangga University, Surabaya, East Java 60131; ${ }^{2}$ Indonesia-Japan Collaborative Research Center for Emerging and Re-emerging Infectious Diseases, Institute of Tropical Disease, Airlangga University; ${ }^{3}$ Institute of Tropical Disease, Airlangga University, Surabaya, East Java 60115, Indonesia; ${ }^{4}$ Center for Infectious Diseases, Kobe University Graduate School of Medicine, Kobe, Hyogo 6500017, Japan;

${ }^{5}$ Department of Biochemistry, School of Medicine, Airlangga University; ${ }^{6}$ Department of Internal Medicine, Dr Soetomo General Hospital, Surabaya, East Java 60131, Indonesia
}

Received March 28, 2013; Accepted May 9, 2013

DOI: $10.3892 /$ br.2013.106

\begin{abstract}
Chronic hepatitis B virus (HBV) infection is a major health problem worldwide, with a particularly high prevalence in the Asian-Pacific region. During chronic hepatitis B virus (HBV) infection, mutations commonly occur in the basal core promoter (BCP) and precore (PC) regions of $\mathrm{HBV}$, affecting $\mathrm{HBeAg}$ expression, particularly following HBeAg seroconversion. Mutations in the B- and T-cell epitopes of the HBV core have also been observed during disease progression. The clinical significance of HBV genome variability has been demonstrated, however the results are a subject of controversy. Considering the characteristics of the virus associated with geographical location, the profiles of BCP, PC and core mutations and their clinical implications in patients with chronic HBV infection in Surabaya, Indonesia, were investigated. The BCP, PC and core mutations and HBV genotypes were detected by direct sequencing. The $\mathrm{HBeAg} /$ anti-HBe status and HBV DNA levels were also assessed. This study enrolled 10 patients with chronic HBV infection (UC) from Dr Soetomo General Hospital and Indonesian Red Cross, Surabaya, East Java, Indonesia, 10 patients with chronic hepatitis B and liver cirrhosis (LC) and 4 patients with chronic hepatitis B and hepatocellular carcinoma (HCC) from Dr Soetomo General
\end{abstract}

Correspondence to: Professor Maria Inge Lusida, Institute of Tropical Disease, Campus C, Airlangga University, Jalan Mulyorejo, Surabaya, East Java 60115, Indonesia

E-mail: ingelusida@yahoo.com

Key words: hepatitis B virus, precore mutations, basal core promoter mutations, core mutations, chronic hepatitis B virus infection
Hospital. The PC mutation A1896 was predominant in all the groups (60-100\%), together with the PC variant T1858, which was associated with HBV genotype B. The number of detected core mutations ( $\mathrm{Thr} / \mathrm{Ser} 130$ ) was higher in HCC patients (50\%). However, the BCP mutations T1762/A1764 were predominant in LC patients (50-60\%). The LC and HCC patients carried $\mathrm{HBV}$ isolates with additional mutations, at least at $\mathrm{BCP}$ or $\mathrm{PC}$, mainly following $\mathrm{HBeAg}$ seroconversion. In the majority of anti-HBe-positive samples, the BCP T1762/A1764 mutations were associated with a high viral load, regardless of the PC 1896 status. In conclusion, the PC mutations were found to be predominant in all the groups. However, the $\mathrm{BCP}$ mutations were mainly detected in the LC group and may be considered as a critical indicator of a poor clinical outcome.

\section{Introduction}

Chronic hepatitis B virus (HBV) infection is a major clinical problem worldwide. It is particularly important in the Asian-Pacific region where the prevalence of HBV infection is high (1), including Indonesia, which belongs to the moderate-to-high hepatitis $\mathrm{B}$ endemic regions $(2,3)$. Chronically infected patients exhibit a wide spectrum of clinical presentations, ranging from an asymptomatic carrier state to chronic active hepatitis B with progression to liver failure, liver cirrhosis (LC) or hepatocellular carcinoma (HCC) $(4,5)$. It has been hypothesized that the genetic variability of the virus, which affects its expression of viral antigens, may also affect the outcome of the infection (6). However, the results of a previous molecular study are a subject of controversy and these issues require further elucidation (7).

It has been suggested that $\mathrm{HBeAg}$ may serve as a decoy to buffer the anti-core protein immune response or to induce immune tolerance in perinatally infected individuals. However, the anti-HBe immune response results in an efficient reduction 
of viral load and thereby provides a strong pressure toward viral variants with reduced or no $\mathrm{HBeAg}$ expression $(8,9)$. Two major types of $\mathrm{HBV}$ variants that frequently occur and affect the expression of $\mathrm{HBeAg}$ are the precore (PC) and the basal core promoter (BCP) mutants (9). The most frequently detected PC mutation is a nucleotide (nt) transition at the codon 28 (A1896) which converts into a TAG stop codon and eliminates $\mathrm{HBeAg}$ expression $(10,11)$. Previously reported evidence suggested that the pattern of PC mutation is restricted by the secondary structure requirements of the $\varepsilon$ encapsidation signals which are essential for viral replication. In order to stabilize this $\varepsilon$ structure, the nt at position 1,896 is paired with the nt at position 1,858 , which is naturally specific for certain $\mathrm{HBV}$ genotypes $(12,13)$. The most common BCP mutations, A1762T and G1764A, result in a decrease of $\mathrm{HBeAg}$ expression, mediated by reduced transcription of PC RNA, but enhance viral replication $(8,14,15)$. Occurrence of these mutations and any additional BCP mutations may confer increased replication efficiency to the virus $(9,16)$. These changes were previously considered to be associated with the HBeAg-negative phenotype. However, more recent studies demonstrated that they may also be found in certain $\mathrm{HBeAg}$-positive patients, particularly those with chronic hepatitis. These BCP mutations may be detected with or without PC mutations (17-19). Core mutations, particularly amino acid (aa) at position 130 exposed on the surface of mature $\mathrm{HBeAg}$, were observed in the course of disease progression and accumulate in the B- and T-cell epitopes $(20,21)$. These findings emphasize the possibility that the mutations in the T- or B-cell epitopes exert a significant effect on T-cell function or subsequent cytokine release and on the association between the host immunological reaction and viral persistence.

A previous study suggested that $\mathrm{HBeAg}$ mutations are associated with chronic hepatitis, LC and HCC (13). However, conflicting evidence suggested that the $\mathrm{HBeAg}$ mutations are present in HBV carriers and in those individuals with mild forms of HBV infection or without liver disease (7). In addition, several core mutations have not been proven to result in loss of immune recognition (22).

The aim of this study was to analyze the profiles of BCP, $\mathrm{PC}$ and core mutations associated with the $\mathrm{HBeAg} / \mathrm{anti}-\mathrm{HBe}$ status and HBV DNA load in patients with chronic HBV infection at various phases in Surabaya, Indonesia. The characteristic of the HBV isolates associated with geographical location may play an important role in these results.

\section{Materials and methods}

Patients and controls. Three groups of patients were investigated: i) the UC group included patients who had been HBsAg-positive for $>6$ months, although without any clinical significance, from Dr Soetomo General Hospital, Surabaya, Indonesia and HBsAg-positive blood donors with asymptomatic liver disease from the Blood Transfusion Unit, Indonesian Red Cross, Surabaya; ii) the LC group included HBV-infected patients with LC; and iii) the HCC group included HBV-infected patients with HCC from Dr Soetomo General Hospital. Determination of the groups from Dr Soetomo General Hospital was performed by clinical and biochemical data; ultrasonographic data were added to confirm the LC and HCC groups. Blood donors were included in the UC group if the laboratory examinations verified immunoglobulin M (IgM) anti-hepatitis B core ( $\mathrm{HBc}$ )-negativity and normal alanine transaminase levels. None of the patients had a history of antiviral drug use. Ethical clearance for the present study was obtained from the Ethics Committee of the Dr Soetomo General Hospital, Surabaya. All the participants signed a consent form.

Serological markers. HBsAg, $\mathrm{HBeAg}$, anti-HBe antibody and other serological markers (anti-HCV and anti-HIV antibodies) were detected by a microparticle enzyme immunoassay (Abbott, Wiesbaden, Germany). Blood donors were screened for IgM anti-HBc to exclude acute HBV infection. The anti-HCV and anti-HIV antibodies were also tested to confirm the absence of exclusion criteria.

Viral DNA extraction, PCR amplification and sequencing. HBV DNA was extracted from each serum sample using the High Pure Viral Nucleic Acid kit (Roche Molecular Systems, Inc., Alameda, CA, USA) following the manufacturer's insructions. The extracted DNA was used as a template for the amplification of the respective gene regions. Polymerase chain reactions (PCRs) were performed with the High Fidelity PCR enzyme mix (Fermentas, Vilnius, Lithuania). The reactions included $2.5 \mu \mathrm{l}$ High Fidelity PCR buffer (with $\mathrm{MgCl}_{2}$ ), $2.5 \mu \mathrm{l}$ dNTP with a concentration of $2 \mathrm{mM}, 0.25 \mu \mathrm{l} \mathrm{High}$ Fidelity PCR enzyme mix, $10 \mu \mathrm{l}$ DNA and $0.5 \mu \mathrm{l}$ of each primer with a concentration of $100 \mathrm{pmol} / \mu \mathrm{l}$, in a total reaction volume of $25 \mu \mathrm{l}$. The thermocycling conditions included a 5-min denaturation step at $94^{\circ} \mathrm{C}$, followed by 40 cycles of $1 \mathrm{~min}$ at $94^{\circ} \mathrm{C}, 1 \mathrm{~min}$ at $55^{\circ} \mathrm{C}$ and $2 \mathrm{~min}$ at $72^{\circ} \mathrm{C} \mathrm{(23).}$

The BCP, PC and partial core genes were amplified in the first round using $\mathrm{HBcl}$ (5'-TTA CAT AAG AGG ACT CTT GG-3', nt 1,650-1,669) and HB9R (5'-GGA TAG AAC TAG CAG GCA T-3', nt 2,654-2,635) (24). If the first-round PCR was negative, the second-round PCR was performed using primers $\mathrm{HBc} 1$ and $\mathrm{HBc} 2$ (5'-TAA AGC CCA GTA AAG TTT CC-3', nt 2,494-2,475) (25).

To elucidate the association between HBV genotype and PC mutations, part of the $\mathrm{S}$ gene was amplified in the first round using primers P7 (5'-GTG GTG GAC TTC TCT CAA TTT TC-3', nt 256-278) and P8 [5'-CGG TAW(A/T) AAA GGG ACT CAM(A/C) GAT-3', nt 796-776]. If the first-round PCR was negative, the second-round PCR was performed using primers HBs1 (5'-CAA GGT ATG TTG CCC GTT TG-3', nt 455-474) and HBs2 (5'-AAA GCC CTG CGA ACC ACT GA-3', nt 713-694) (23). The nt sequences of the amplified fragments were determined using the BigDye Terminator v1.1 Cycle Sequencing kit with an ABI Prism 310 (Applied Biosystems, Foster City, CA, USA).

Sequences analyses for the detection of BCP, PC and core mutations. All sequence data analyses were performed with Genetyx-Windows version 9 (Software Development Co., Ltd., Tokyo, Japan). After aligning the sequences obtained from this study and from International DNA databases (DDBJ/EMBL/GenBank), the variability of the BCP, PC and core was analyzed. The HBV genotypes were determined based on the homologous percentage of $>96 \%$ in the $\mathrm{S}$ and/or core 
Table I. Number of BCP, PC and core mutations in various clinical stages of chronic HBV infection.

No. of HBV mutations/variants

\begin{tabular}{|c|c|c|c|c|c|c|c|c|}
\hline \multirow[b]{2}{*}{ Clinical stage } & \multirow[b]{2}{*}{ No. } & \multicolumn{2}{|c|}{$\mathrm{BCP}$} & \multicolumn{3}{|c|}{$\mathrm{PC}$} & \multicolumn{2}{|c|}{ Core } \\
\hline & & T1762 (\%) & A1764 (\%) & T1858 (\%) & $\mathrm{A} 1896(\%)$ & A1899 (\%) & Leu97 (\%) & Thr/Ser130 (\%) \\
\hline $\mathrm{UC}$ & 10 & $2 / 10(20)$ & $2 / 10(20)$ & $10 / 10(100)$ & $6 / 10(60)$ & $3 / 10^{\mathrm{b}}(30)$ & $3 / 10(30)$ & $1 / 10^{\mathrm{d}}(10)$ \\
\hline $\mathrm{LC}$ & 10 & $6 / 10(60)$ & $5 / 10(50)$ & $10 / 10(100)$ & $6 / 10(60)$ & $2 / 10^{\mathrm{a}}(20)$ & $4 / 10(40)$ & $3 / 10^{\mathrm{e}}(30)$ \\
\hline $\mathrm{HCC}$ & 4 & $1 / 4(25)$ & $1 / 4(25)$ & 4/4 (100) & $4 / 4(100)$ & 0/4 (0) & $2 / 4(50)$ & $2 / 4^{\mathrm{c}}(50)$ \\
\hline Total & 24 & $9 / 24(38)$ & $8 / 24(33)$ & $24 / 24(100)$ & $16 / 24(67)$ & $5 / 24(21)$ & $9 / 24(38)$ & $6 / 24(25)$ \\
\hline
\end{tabular}

Mutations of BCP and PC are presented at nucleotide positions, but core mutations are presented at amino acid (aa) positions. ${ }^{\mathrm{a} O n e}$ sample exhibited combined PC A1899 and PC A1896 mutations; btwo samples exhibited combined PC A1899 and PC A1896 mutations; 'all the core mutations at aa 130 were Thr130, however, 1 sample in the HCC group exhibited Ser130 mutation; ${ }^{\mathrm{d}}$ one sample exhibited combined Thr130 and Leu97 core mutations; ' hepatitis B virus; UC, chronic HBV infection; LC, liver cirrhosis; HCC, hepatocellular carcinoma; Leu, leucine; Thr, threonine; Ser, serine.

Table II. Patterns of BCP, PC and core mutations in various clinical stages of chronic HBV infection.

Patterns of BCP, PC and core mutations

Clinical stage No. BCP+ PC- $-\mathrm{BCP}+\mathrm{PC}+\mathrm{C}-\mathrm{BCP}+\mathrm{PC}-\mathrm{C}+\mathrm{BCP}+\mathrm{PC}+\mathrm{C}+\mathrm{BCP}-\mathrm{PC}+\mathrm{C}-\quad \mathrm{BC}-\mathrm{PC}+\mathrm{C}+\mathrm{BCP}-\mathrm{PC}-\mathrm{C}-$

\begin{tabular}{|c|c|c|c|c|c|c|c|c|}
\hline UC & 10 & - & $2(20 \%)$ & - & - & $2(20 \%)$ & $3(30 \%)$ & $3(30 \%)$ \\
\hline $\mathrm{LC}$ & 10 & $2(20 \%)$ & $1(10 \%)$ & $1(10 \%)$ & $2(20 \%)$ & $2(20 \%)$ & $2(20 \%)$ & - \\
\hline $\mathrm{HCC}$ & 4 & - & - & - & $1(25 \%)$ & $1(25 \%)$ & $2(50 \%)$ & - \\
\hline Total & 24 & $2(8 \%)$ & $3(13 \%)$ & $1(4 \%)$ & $3(13 \%)$ & $5(21 \%)$ & $7(29 \%)$ & $3(13 \%)$ \\
\hline
\end{tabular}

BCP mutations, mutations of T1762/A1764 in the BCP region; PC mutations, mutations of A1896 and/or A1899 in the PC region; C mutations, mutations of Leu97 and/or Thr/Ser130 in the core region; +, mutant type; -, wild-type. BCP, basal core promoter; PC, precore; C, core; HBV, hepatitis B virus; UC, chronic HBV infection; LC, liver cirrhosis; HCC, hepatocellular carcinoma; Leu, leucine; Thr, threonine; Ser, serine.

gene sequences compared to HBV isolates from International DNA databases (DDBJ/EMBL/GenBank) $(26,27)$.

Quantification of $H B V D N A$. The HBV DNA level was determined with the COBAS Amplicor HBV monitor (Roche Molecular Systems, Inc., Branchburg, NJ, USA).

INNO-LiPA PC assay. The INNO-LiPA PreCore kit (Innogenetics, Ghent, Belgium) was used to assess serum samples (with A1896 PC mutation but HBeAg-positive) which could not be assessed by direct sequencing. The kit is able to detect a wild-type/mutant mixed population of circulating virus.

\section{Results}

Profiles of BCP, PC and core mutations and HBV genotype. A total of $29 \mathrm{HBs} A g$-positive serum samples were obtained from patients and control subjects. In 24 of the 29 samples the sequences of BCP, PC and core regions were detected and confirmed. The samples were collected from 10 patients with UC, 10 with LC and 4 patients with HCC. All 24 subjects were aged 22-68 years (mean age, 43.8 years) and included 18 men and 6 women. Their descent was from Java (88\%), Flores
(4\%), Sulawesi (4\%) and Aceh-Batak (4\%) and they resided in Surabaya.

In the 24 serum samples, the most frequently detected mutation in the PC region was A1896 (67\%) and it was predominant in all the groups (60-100\% of each group) (Table I). The PC A1896 mutation was encountered in all isolates identified as genotype B (data not shown). Based on part of the $\mathrm{S}$ and/ or core genes, the 24 isolates were classified into HBV genotype $\mathrm{B}$. The association between genotype $\mathrm{B}$ and the $\mathrm{PC}$ variant T1858 was $100 \%$. The other PC mutation, A1899, was detected in $21 \%$ isolates $(5 / 24)$ and in some of them it was observed in combination with A1896 (3/5, 60\%). In the BCP region, T1762 and A1764 mutations were detected in $38 \%$ and $33 \%$ isolates, respectively, and these mutations were predominant in the LC group (50-60\%). Mutations in the core region aa 130 were detected in six (25\%) isolates (10-50\% of each group), mostly in the HCC group. The obtained mutation types in core aa 130 included Thr130 (five isolates) and Ser130 (one isolate). The other core mutation, Leu97, was encountered in 38\% isolates (30-50\% of each group). The core mutations, Thr130 combined with Leu97, were observed in three isolates $(3 / 5,60 \%)$.

To simplify data analysis, this study focused on BCP T1762/A1764,PC A1896 and core Thr/Ser130 as the well-known hotspot mutations. The mutations of PC A1899 and core Leu97 
Table III. Status of HBeAg/anti-HBe in various clinical stages of chronic HBV infection.

\begin{tabular}{lcccc}
\hline & & \multicolumn{3}{c}{ Status of $\mathrm{HBeAg} / \mathrm{anti-HBe}(\%)$} \\
\cline { 3 - 5 } Clinical stage & No. & $\operatorname{HBeAg}(+) / \operatorname{anti}-\mathrm{HBe}(-)$ & $\operatorname{HBeAg}(-) / \operatorname{anti-HBe}(+)$ & $\operatorname{HBeAg}(-) / \operatorname{anti-HBe}(-)$ \\
\hline UC & 10 & $3(30)$ & $6(60)$ & $1(10)$ \\
LC & 10 & $3(30)$ & $7(70)$ & 0 \\
HCC & 4 & 0 & $4(100)$ & 0 \\
Total & 24 & $6 / 24(25)$ & $17 / 24(71)$ & $1 / 24(4)$ \\
\hline
\end{tabular}

HBV, hepatitis B virus; UC, chronic HBV infection; LC, liver cirrhosis; HCC, hepatocellular carcinoma; (+), positive; (-), negative.

Table IV. BCP, PC and core mutations of HBV prior to and following HBeAg seroconversion.

\begin{tabular}{|c|c|c|c|c|c|c|c|c|c|c|c|}
\hline \multirow[b]{3}{*}{ Time point } & \multirow[b]{3}{*}{ No. } & \multirow{2}{*}{\multicolumn{2}{|c|}{$\frac{\text { ВСР }}{\text { nt } 1762 / 1764}$}} & \multicolumn{4}{|c|}{ PC } & \multicolumn{4}{|c|}{ Core } \\
\hline & & & & \multicolumn{2}{|c|}{ nt 1896} & \multicolumn{2}{|c|}{ nt 1899} & \multicolumn{2}{|c|}{ aa 97} & \multicolumn{2}{|c|}{ aa 130} \\
\hline & & WT (\%) & MT (\%) & WT (\%) & MT (\%) & WT (\%) & MT (\%) & WT (\%) & MT (\%) & WT (\%) & MT (\%) \\
\hline $\begin{array}{l}\text { Prior to } \\
\text { SC }\end{array}$ & 6 & $4(66.7)$ & $2(33.3)$ & $4(66.7)$ & $2(33.3)$ & $6(100)$ & 0 & $4(66.7)$ & $2(33.3)$ & $4(66.7)$ & $2(33.3)$ \\
\hline $\begin{array}{l}\text { Following } \\
\text { SC }\end{array}$ & 17 & $10(58.9)$ & $7(41.2)$ & $3(23.5)$ & $14(76.5)$ & $12(70.6)$ & $5(29.4)$ & $10(58.9)$ & $7(41.2)$ & $13(76.5)$ & $4(23.5)$ \\
\hline
\end{tabular}

BCP, basal core promoter; PC, precore; HBV, hepatitis B virus; nt, nucleotide; aa, amino acid; WT, wild-type; MT, mutant type; SC, seroconversion.

were also included, since they could be found in combination and share certain effects with the mutations mentioned above (PC A1896 with A1899 and core Leu97 with Thr/Ser130) (Table II). There were several basic pattern possibilities, i.e., no mutations (BCP- PC- C-), BCP mutation only (BCP+ PC- C-), $\mathrm{BCP}$ and $\mathrm{PC}$ mutations $(\mathrm{BCP}+\mathrm{PC}+\mathrm{C}-), \mathrm{BCP}$ and $\mathrm{C}$ mutations $(\mathrm{BCP}+\mathrm{PC}-\mathrm{C}+), \mathrm{PC}$ mutation only $(\mathrm{BCP}-\mathrm{PC}+\mathrm{C}-), \mathrm{PC}$ and core mutations (BCP- $\mathrm{PC}+\mathrm{C}+$ ), core mutation only (BCP- $\mathrm{PC}-\mathrm{C}+$ ) and triple mutations $(\mathrm{BCP}+\mathrm{PC}+\mathrm{C}+)$. The pattern of core mutation only (BCP- PC- $\mathrm{C}+$ ) was not detected in this study. The LC and HCC groups carried HBV isolates with additional mutations, at least BCP or PC mutations. The LC group mainly carried HBV with BCP mutations $(60 \%)$, whereas the HCC group commonly exhibited PC mutations (100\%). The triple mutation pattern $(\mathrm{BCP}+\mathrm{PC}+\mathrm{C}+)$ was only detected in the LC and HCC groups; however, the BCP- PC- C- pattern was absent in the UC group.

Status of HBeAg/anti-HBe and HBV DNA level associated with $B C P, P C$ and core mutations. Of the 24 serum samples, $\mathrm{HBeAg-negative/anti-HBe-positive} \mathrm{was} \mathrm{the} \mathrm{predominant}$ type $(71 \%)$, followed by $\mathrm{HBeAg}$-positive/anti-HBe-negative (25\%) and $\mathrm{HBeAg-negative/anti-HBe-negative} \mathrm{(4 \% ).}$ Anti-HBe-positive was predominant in the HCC group (100\%), followed by the LC (70\%) and UC (60\%) groups (Table III).

In the six $\mathrm{HBeAg}$-positive serum samples (prior to seroconversion), the number of wild-types of BCP (A1762/G1764), PC (G1896 and G1899) and core (Ile97 and Pro130) was higher (range, 66.7-100\%) compared with the number of mutant types of BCP (T1762/A1764), PC (A1896 and A1899) and core
(Thr/Ser130) (Table IV). As determined by the INNO-LiPA assay, the two samples from patient 7RS (UC group) and patient 17RS (LC group) that were $\mathrm{HBeAg}$-positive in the presence of the PC A1896 mutation, had mixed strains of mutant and wild-types of the PC region.

Following $\mathrm{HBeAg}$ seroconversion, the number of the mutant types of BCP nt 1,762/1,764 was lower compared to the wild-types, although the number was increased compared to prior to seroconversion. However, the number of core mutations Thr/Ser130 was lower following compared to prior to seroconversion. Of note, the number of the mutant type of PC A1896 mutations was significantly higher (82.4\%) in anti-HBe-positive serum samples compared to that of wild-type mutations (17.7\%) (Table IV).

Following HBeAg seroconversion, the mutant types of BCP (T1762/A1764) were frequently associated with a high level of HBV DNA (57.1\%). However, the number of serum samples with the mutant type of PC A1896 exhibiting low HBV DNA levels and that of samples with high HBV DNA levels were identical. Of the three samples with the mutant type of combined PC A1899 and PC A1896, two were associated with a low level of HBV DNA (Table V).

\section{Discussion}

$\mathrm{HBV}$ mutations in the $\mathrm{PC}, \mathrm{BCP}$ and core regions have been reported to exert various effects on the clinical course of patients with HBV-related liver diseases (28). In this study, these mutations were assessed in various phases of chronic hepatitis B infection in Surabaya, Indonesia. 
Table V. Mutations of BCP, PC and core according to the HBV DNA level in anti-HBe(+) samples.

HBV DNA level

Mutations of $\mathrm{HBeAg}$

Low $[<5 \log$ copies/ml (\%)]

High [ $\geq 5 \log$ copies/ml (\%)]

\begin{tabular}{lrr}
\hline BCP T1762/A1764 & $3 / 7(42.9)$ & $4 / 7(57.1)$ \\
PC A1896 & $7 / 14(50)$ & $7 / 14(50)$ \\
PC A1899+A1896 & $2 / 3(66.7)$ & $1 / 3(33.3)$
\end{tabular}

$\mathrm{BCP}$, basal core promoter; PC, precore; HBV, hepatitis B virus; (+), positive.

In the $\mathrm{PC}$ region, the predominant mutation is a G-to-A change at nt 1,896 (A1896), which creates a premature stop codon and eliminates the synthesis of $\mathrm{HBeAg}(29)$. A previous study demonstrated that $\mathrm{HBeAg}$ may be a target antigen on HBV-infected hepatocytes (30) and failure to produce a target antigen may be a means of evading immune clearance. It was reported that there is a significant association between PC mutations and remission of liver disease (31). However, other studies reported a high prevalence of PC mutations in patients with severe liver disease (32-34). The results of this study have demonstrated that in the PC region, the A1896 mutant was predominant in patients with HCC (100\%) and those with LC (60\%), although it was also found in UC patients (60\%) (Table I). The variability in the prevalence of the A1896 mutant in different geographical regions is associated with the predominant HBV genotype, since this mutant is restricted to the HBV genotypes with $\mathrm{T}$ at nt 1,858 and is not encountered in those with $\mathrm{C}$ at nt $1,858(13,35)$. The A1896 and T1858 tighten the stem structure by forming a T-A pair (12), although T1858 may also form a wobble pairing with G1896 (11). The PC A1896 is found only in patients infected with HBV genotypes B, D, E and in a minority of those infected with the $\mathrm{C}$ and $\mathrm{F}$ strains that bear a variant $\mathrm{T}$ at nt $1,858(36,37)$. In accordance with previous studies $(23,38)$, this study has demonstrated that HBV genotype B was predominant, detected in all 24 serum samples collected mainly from individuals of Java origin (88\%), as well as of Sulawesi, Aceh-Batak and Flores origin (4\% each) who resided in Surabaya. The HBV genotypes also appear to be associated with ethnic origin. However, the association between the A1896 in the PC region and other genotypes could not be elucidated in this study. As regards clinical outcomes, our results were in accordance with those previously reported (39), stating that A1896 alone may have no direct pathogenic role, particularly in $\mathrm{HBV}$ isolates with genotypes harbouring T1858. The other PC mutation, A1899, was detected in three serum samples combined with A1896. These combined mutations may enhance the stability of the stem loop which is essential for viral replication (40). However, in this study, in two out of the three samples, low HBV DNA levels were detected (Table V). Additional studies are required to confirm the significance of these mutations on viral replication.

In the $\mathrm{BCP}$ region, the most common mutations involve a two-nt substitution: A-T at nt 1,762 and G-A at nt 1,764 (T1762 and A1764) (17). Previous transfection studies demonstrated that the T1762 and A1764 mutations decrease the level of pre-C mRNA by $50-70 \%$ and lead to reduced HBeAg synthesis $(14,41)$. The BCP mutants may enhance HBV virulence by increasing host immune response to HBV-infected hepatocytes, increasing viral replication or altering the coding region for the $\mathrm{X}(14,15,42,43)$. The BCP T1762/A1764 were found in patients of the HCC (25\%) and UC (20\%) groups, although the majority was encountered in the LC group (50-60\%) (Table I). This finding was in agreement with a previous study which reported that BCP mutations were found mainly in cirrhotic tissues with a lower incidence in HCC tissues (44). Of note, the majority of isolates $(55.5 \%, 5 / 9)$ with BCP T1762/A1764 were not accompanied by PC A1896. It was suggested that BCP mutations frequently emerge during the late $\mathrm{HBeAg}$ phase of infection, whereas PC mutations usually emerge later, at the height of the anti-HBe immune response (9). In this study, the two HBeAg-positive serum samples with BCP mutations exhibited no concomitant PC mutation; however, four out of the seven anti-HBe-positive samples with BCP mutations also exhibited PC mutations.

Mutant HBV may also exhibit enhanced virulence with alteration of epitopes which is critical for the host immune response. Mutations in B- and T-cell epitopes are associated with viral persistence, affecting the host immune response (45-47). The inflammatory activity produced by viral adaptive mechanisms may persist in up to $15 \%$ of cases, leading to the development of cirrhosis (48). A previous study by Hosono et al (20) suggested that core mutations in HBV accumulated more errors in tumors compared to non-tumors. The aa 120-140 in the core region exposed on the surface of mature $\mathrm{HBeAg}$ and $\mathrm{HBcAg}$ are related to the recognition of helper $\mathrm{T}$ cells (49-51) and the immunodominant B-cell recognition sites within the $\mathrm{HBcAg}$ have also been found around residues 126-135 (45,46). One of the frequent core mutations is at aa 130 , predominated by Thr130 [67 out of $96(70 \%)$ ]. It was noted that Thr130 was frequently associated with the occurrence of Leu97 [50 out of $67(75 \%)$ ], although it may occur per se [17 out of 67 (25\%)] (52). The Ser130 mutation was also reported to affect cellular and humoral immunity, since the codon is part of a domain which is recognized by B and T cells (53). The Leu97 of HBcAg was reported to enable the virus to secrete an excessive amount of immature genome with nascent incomplete single-strand DNA in an envelope-dependent manner, leading to attenuation of the total yield of mutant virus production $(52,54,55)$. However, this excessive secretion of incomplete virions may be offset by an additional mutation at codon 130 (Pro to Thr/Ser) $(52,53)$. In 
this study, the Thr/Ser130 mainly occurred in the HCC group $(2 / 4,50 \%)$, followed by the LC (30\%) and UC (10\%) groups. The Thr/Ser130 was mostly detected in combination with Leu97 (Table I).

Certain combined mutations in the BCP, PC and core regions are of higher clinical significance regarding the severity of liver disease. In this study, patients with LC and HCC carried HBV with mutations of at least BCP or PC. Some patients with UC also carried the HBV mutation; however, more mutations were likely to be associated with LC and HCC (Table II). The combination of mutations rather than a single mutation was associated with the development of progressive liver disease (56).

The most frequently encountered variant of chronic $\mathrm{HBV}$ infections is $\mathrm{HBeAg-negative} \mathrm{chronic} \mathrm{hepatitis} \mathrm{B.} \mathrm{It}$ may follow seroconversion from $\mathrm{HBeAg}$ to anti-HBe antibodies during the immune reactive phase or develop after years or decades of inactive carrier state. The patients are $\mathrm{HBeAg-negative} \mathrm{and} \mathrm{harbour} \mathrm{a} \mathrm{predominance} \mathrm{of} \mathrm{HBV}$ virions with nt substitutions in the $\mathrm{PC}$ and/or the $\mathrm{BCP}$ regions that lead to absent or low expression levels of $\mathrm{HBeAg}(5,57)$. $\mathrm{HBeAg}$-negative mutants frequently become the predominant virus population in chronic HBsAg carriers, possibly indicating a selection advantage against the wild-type $(10,17)$. This study has demonstrated that HBeAg-negative/anti-HBe -positive was the predominant type (71\%) in all the groups, particularly in the HCC group (100\%) (Table III). Following seroconversion, PC A1896 was predominant and the number of the BCP T1762/A1764 mutations was increased (Table IV). In the majority of anti-HBe-positive serum samples, the BCP T1762/A1764 was mostly correlated with a high viral load ( $\geq 10^{5}$ copies $/ \mathrm{ml}$ ), but PC A1896 was not correlated with viral load level (Table V). This finding was in agreement with previously reported results (58), suggesting that patients with the BCP T1762/A1764 mutant exhibited significantly higher serum HBV DNA levels compared to those with the $\mathrm{BCP}$ A1762/G1764 wild-type strain, regardless of the PC 1896 status. The BCP mutations were found in the dominant viral species at the late $\mathrm{HBeAg}$-positive and early anti-HBe phases of HBV infection. Thus, chronic hepatitis B patients infected with the T1762 and A1764 mutants may have a longer duration of active replication (58). The number of the core mutation Thr130 was lower following seroconversion compared with prior to seroconversion (Table IV). The duration of seroconversion from $\mathrm{HBeAg}$ to anti-HBe may be attributed to the extent of immunological attacks against the HBV core region.

Of note, two serum samples collected from one patient of the UC (7RS) and one of the LC group (17RS) were HBeAg-positive in the presence of the PC A1896 mutation. This observation may be due to the presence of a mixed infection by the mutant- and wild-type viruses. The presence of the wild-type virus is required by certain mutants for the infection of hepatocytes. It is likely that HBV exists as a quasi species of wild-type and mutant clones, even in the HBeAg-positive phase (7). To determine any mixed infection (59), the two samples were examined by the INNO-LiPA assay and it was confirmed that they had mixed strains of mutant and wild-type PC. A heterogeneous virus population circulating in patients with chronic HBV infection may thus determine the outcome of infection.
In conclusion, the PC mutation A1896 was predominant in all the groups and the BCP mutations T1762/A1764 were only predominant in patients with chronic hepatitis B and LC. The BCP mutations may be considered as a more efficient indicator of a poor outcome compared to the PC mutations. Additional studies are required, including a larger population, to determine which type of specific mutations or combined mutations is associated with liver disease severity and may thus be involved in the pathogenetic process.

\section{Acknowledgements}

The authors are grateful to Slamet Riyadi, Nur Achmad Tjipto and Nasronudin for their cooperation and to Mochamad Amin and Koen Poedijati for their technical assistance. We are also grateful to the patients at Dr Soetomo General Hospital, Surabaya and the blood donors at the Blood Transfusion Unit-Indonesia Red Cross, Surabaya, who provided the blood samples for this study. This study was supported by a grant from the Directorate General of Higher Education, Department of National Education, Indonesia and by the Japan Initiative for Global Research Network on Infectious Diseases, the Ministry of Education, Culture, Sports, Science and Technology, Japan.

\section{References}

1. Liaw YF, Leung N, Kao JH, et al: Asian-Pacific consensus statement on the management of chronic hepatitis B: a 2008 update. Hepatol Int 2: 263-283, 2008.

2. Sastrosoewignjo RI, Sandjaja B and Okamoto H: Molecular epidemiology of hepatitis B virus in Indonesia. J Gastroenterol Hepatol 6: 491-498, 1991.

3. Khan M, Dong JJ, Acharya SK, et al: Hepatology issues in Asia: perspective from regional leaders. J Gastroenterol Hepatol 19: S419-S430, 2004.

4. Chu CM, Karayiannis P, Fowler MJ, Monjardino J, Liaw YF and Thomas HC: Natural history of chronic hepatitis B virus infection in Taiwan: studies of hepatitis B virus DNA in serum. Hepatology 5: 431-434, 1985.

5. Hadziyannis SJ and Vassilopoulos D: Hepatitis B e antigen-negative chronic hepatitis B. Hepatology 34: 617-624, 2001.

6. Lau JY and Wright TL: Molecular virology and pathogenesis of hepatitis B. Lancet 342: 1335-1340, 1993.

7. Davidson F, Lycett C, Sablon E, Petrik J and Dow BC: Hepatitis B virus genotypes and precore mutations in Scottish blood donors. Vox Sang 88: 87-92, 2005.

8. Locarnini S, McMillan J and Bartholomeusz A: The hepatitis B virus and common mutants. Semin Liver Dis 23: 5-20, 2003.

9. Parekh S, Zoulim F, Ahn SH, et al: Genome replication, virion secretion, and e antigen expression of naturally occurring hepatitis B virus core promoter mutants. J Virol 77: 6601-6612, 2003.

10. Okamoto H, Yotsumoto S, Akahane Y, et al: Hepatitis B viruses with precore region defects prevail in persistently infected hosts along with seroconversion to the antibody against e antigen. J Virol 64: 1298-1303, 1990.

11. Kao JH: Hepatitis B viral genotypes: clinical relevance and molecular characteristics. J Gastroenterol Hepatol 17: 643-650, 2002.

12. Lok AS, Akarca U and Greene S: Mutations in the precore region of hepatitis B virus serve to enhance the stability of the secondary structure of the pre-genome encapsidation signal. Proc Natl Acad Sci USA 91: 4077-4081, 1994.

13. Rodriguez-Frias F, Buti M, Jardi R, Cotrina M, Viladomiu L, Esteban R and Guardia J: Hepatitis B virus infection: precore mutants and its relation to viral genotypes and core mutations. Hepatology 22: 1641-1647, 1995.

14. Buckwold VE, Xu Z, Chen M, Yen TS and Ou JH: Effects of a naturally occurring mutation in the hepatitis B virus basal core promoter on precore gene expression and viral replication. J Virol 70: 5845-5851, 1996. 
15. Hunt CM, McGill JM, Allen MI and Condreay LD: Clinical relevance of hepatitis B virus mutations. Hepatology 31: 1037-1044, 2000.

16. Baumert TF, Rogers SA, Hasegawa K and Liang TJ: Two core promoter mutations identified in a hepatitis B virus strain associated with fulminant hepatitis result in enhanced viral replication. J Clin Invest 98: 2268-2276, 1996.

17. Okamoto H, Tsuda F, Akahane Y, et al: Hepatitis B virus with the mutations in the core promoter for an e antigen-negative phenotype in carriers with antibody to e antigen. J Virol 68: 8102-8110, 1994

18. Kidd-Ljunggren K, Oberg M and Kidd AH: Hepatitis B virus X gene 1751 to 1764 mutations: implications for HBeAg status and disease. J Gen Virol 78: 1469-1478, 1997.

19. European Association for the Study of the Liver (EASL): EASL clinical practice guidelines: management of chronic hepatitis B. J Hepatol 50: 227-242, 2009.

20. Hosono S, Tai PC, Wang W, et al: Core antigen mutation of human hepatitis B virus in hepatomas accumulate in MHC class II-restricted T cell epitopes. Virology 212: 151-162, 1995.

21. Okumura A, Ishikawa T, Yoshioka K, Yuasa R, Fukuzawa Y and Kakumu S: Mutation at codon 130 in hepatitis B virus (HBV) core region increases markedly during acute exacerbation of hepatitis in chronic HBV carriers. J Gastroenterol 36: 103-110, 2001.

22. World Health Organization: Hepatitis B, 2002. http://www who.int/csr/disease/hepatitis/whocdscsrlyo20022/en/. Accessed February 1, 2006.

23. Lusida MI, Surayah, Sakugawa H, et al: Genotype and subtype analyses of hepatitis B virus (HBV) and possible co-infection of $\mathrm{HBV}$ and hepatitis $\mathrm{C}$ virus (HCV) or hepatitis D virus (HDV) in blood donors, patients with chronic liver disease and patients on hemodialysis in Surabaya, Indonesia. Microbiol Immunol 47: 969-975, 2003

24. Sugauchi F, Mizokami M, Orito E, et al: A novel variant genotype $\mathrm{C}$ of hepatitis $\mathrm{B}$ virus identified in isolates from Australian Aborigines: complete genome and phylogenetic relatedness. J Gen Virol 82: 883-892, 2001.

25. Lusida MI, Nugrahaputra VE, Soetjipto, et al: Novel subgenotypes of hepatitis B virus genotypes C and D in Papua, Indonesia. J Clin Microbiol 46: 2160-2166, 2008.

26. Magnius LO and Norder H: Subtypes, genotypes and molecular epidemiology of the hepatitis B virus as reflected by sequence variability of the $S$-gene. Intervirology 38: 24-34, 1995.

27. Arauz-Ruiz P, Norder H, Visona KA and Magnius LO: Molecular epidemiology of hepatitis B virus in Central America reflected in the genetic variability of the small S gene. J Infect Dis 176: 851-858, 1997.

28. Liu Y, Zhong Y, Zou Z, et al: Features and clinical implications of hepatitis B virus genotypes and mutations in basal core promoter/precore region in 507 Chinese patients with acute and chronic hepatitis B. J Clin Virol 47: 243-247, 2010

29. Carman WF, Jacyna MR, Hadziyannis S, Karayiannis P, McGarvey MJ, Makris A and Thomas HC: Mutation preventing formation of hepatitis $\mathrm{B}$ e antigen in patients with chronic hepatitis B infection. Lancet 2: 588-591, 1989.

30. Schlicht HJ and Schaller H: The secretory core protein of human hepatitis B virus is expressed on the cell surface. J Virol 63 5399-5404, 1989

31. Chan HL, Hussain M and Lok AS: Different hepatitis B virus genotypes are associated with different mutations in the core promoter and precore regions during hepatitis B e antigen seroconversion. Hepatology 29: 976-984, 1999.

32. Chisari FV: Perspectives series: host/pathogen interactions Cytotoxic T cells and viral hepatitis. J Clin Invest 99: 1472-1477, 1997.

33. Friedt M, Gerner P, Lausch E, Trubel H, Zabel B and Wirth S: Mutations in the basic core promoter and the precore region of hepatitis B virus and their selection in children with fulminan and chronic hepatitis B. Hepatology 29: 1252-1258, 1999.

34. Kao JH, Chen PJ, Lai MY and Chen DS: Clinical and virological aspects of blood donors infected with hepatitis B virus genotypes B and C. J Clin Microbiol 40: 22-25, 2002.

35. Lindh M, Anderson AS and Gusdal A: Genotypes, nt 1858 variants, and geographic origin of hepatitis B virus - large-scale analysis using a new genotyping method. J Infect Dis 175: 1285-1293, 1997

36. Hadziyannis SJ: Hepatitis B e antigen-negative chronic hepatitis B: from clinical recognition to pathogenesis and treatment. Viral Hepat Rev 1: 7-36, 1995.

37. Kramvis A and Kew MC: Relationship of genotypes of hepatitis B virus to mutations, disease progression and response to antiviral therapy. J Viral Hepat 12: 456-464. 2005.
38. Mulyanto, Depamede SN, Surayah K, Tsuda F, Ichiyama K, Takahashi M and Okamoto H: A nationwide molecular epidemiological study on hepatitis B virus in Indonesia: identification of two novel subgenotypes, B8 and C7. Arch Virol 154: 1047-1059, 2009.

39. Zarski JP, Marcellin P, Cohard M, Lutz JM, Bouche C and Rais A Comparison of anti-HBe-positive and $\mathrm{HBe}$-antigen-positive chronic hepatitis B in France. Multicentre Group. J Hepatol 20: 636-640, 1994

40. Chan HL, Ghany MG and Lok ASF: Hepatitis B. In: Schiff's Diseases of the Liver. Schiff ER, Sorrell MF and Maddrey WC (eds). Vol 1. 8th edition. Lippincott Williams and Wilkins, Philadelphia, pp757-791, 1999.

41. Günther S, Piwon N and Will H: Wild-type levels of pregenomic RNA and replication but reduced pre-C RNA and e-antigen synthesis of hepatitis B virus with $\mathrm{C}(1653) \rightarrow \mathrm{T}, \mathrm{A}(1762) \rightarrow \mathrm{T}$ and $\mathrm{G}(1764) \rightarrow$ A mutations in the core promoter. J Gen Virol 79: 375-380, 1998.

42. Kidd-Ljunggren K, Oberg M and Kidd AH: The hepatitis B virus X gene: analysis of functional domain variation and gene phylogeny using multiple sequences. J Gen Virol 76: 2119-2130, 1995.

43. Li J, Buckwold VE, Hon MW and Ou JH: Mechanism of suppression of hepatitis B virus precore RNA transcription by a frequent double mutation. J Virol 73: 1239-1244, 1999.

44. Cho SW, Shin YJ, Hahm KB, Jin JH, Kim YS, Kim JH and Kim HJ: Analysis of the precore and core promoter DNA sequence in liver tissues from patients with hepatocellular carcinoma. J Korean Med Sci 14: 424-430, 1999.

45. Bozkaya $\mathrm{H}$, Ayola $\mathrm{B}$ and Lok AS: High rate of mutations in the hepatitis B core gene during the immune clearance phase of chronic hepatitis B virus infection. Hepatology 24: 32-37, 1996.

46. Pumpens $\mathrm{P}$ and Grens E: HBV core particles as a carrier for B cell/T cell epitopes. Intervirology 44: 98-114, 2001.

47. Alexopoulou A, Baltayiannis G, Eroglu C, Nastos T, Dourakis SP, Archimandritis AJ and Karayiannis P: Core mutations in patients with acute episodes of chronic HBV infection are associated with the emergence of new immune recognition sites and the development of high IgM anti-HBc index values. J Med Virol 81: 34-41, 2009.

48. Hsu YS, Chien RN, Yeh CT, Sheen IS, Chiou HY, Chu CM and Liaw YF: Long-term outcome after spontaneous HBeAg seroconversion in patients with chronic hepatitis B. Hepatology 35 : $1522-1527,2002$

49. Sallberg M, Ruden U, Wahren B, Noah M and Magnius LO Human and murine B cells recognize the $\mathrm{HBeAg} /$ beta (or $\mathrm{HBe} 2$ ) epitope as a linear determinant. Mol Immunol 28: 719-726, 1991.

50. Milich DR, Peterson DL, Schodel F, Jones JE and Hughes JL: Preferential recognition of hepatitis $B$ nucleocapsid antigens by Th1 or Th2 cells is epitope and major histocompatibility complex dependent. J Virol 69: 2776-2785, 1995.

51. Milich DR, Schodel F, Hughes JL, Jones JE and Peterson DL: The hepatitis B virus core and e antigens elicit different Th cell subsets: antigen structure can affect Th cell phenotype. J Virol 71: 2192-2201, 1997

52. Yuan TT and Shih C: A frequent, naturally occurring mutation (P130T) of human hepatitis B virus core antigen is compensatory for immature secretion phenotype of another frequent variant (I97L). J Virol 74: 4929-4932, 2000.

53. Kreutz C: Molecular, immunological and clinical properties of mutated hepatitis B viruses. J Cell Mol Med 6: 113-143, 2002.

54. Yuan TT, Sahu GK, Whitehead WE, Greenberg R and Shih C: The mechanism of an immature secretion phenotype of a highly frequent naturally occurring missense mutation at codon 97 of human hepatitis B virus core antigen. J Virol 73: 5731-5740, 1999

55. Yuan TT, Tai PC and Shih C: Subtype-independent immature secretion and subtype-dependent replication deficiency of a highly frequent, naturally occurring mutation of human hepatitis B virus core antigen. J Virol 73: 10122-10128, 1999.

56. Lin CL and Kao JH: Hepatitis B viral factors and clinical outcomes of chronic hepatitis B. J Biomed Sci 15: 137-145, 2008.

57. Hadziyannis SJ and Papatheodoridis GV: Hepatitis B e antigen-negative chronic hepatitis B: natural history and treatment. Semin Liver Dis 26: 130-141, 2006.

58. Lin CL, Liao LY, Liu CJ, et al: Hepatitis viral factors in $\mathrm{HBeAg-negative} \mathrm{carriers} \mathrm{with} \mathrm{persistently} \mathrm{normal} \mathrm{serum} \mathrm{alanine}$ aminotransferase levels. Hepatology 45: 1193-1198, 2007.

59. Abbas Z, Muzaffar R, Siddiqui A, Naqvi SA and Rizvi SA: Genetic variability in the precore and core promoter regions of hepatitis B virus strains in Karachi. BMC Gastroenterol 6: 20, 2006. 